\title{
A new species of Chaetothyrina on branches of mango, and introducing Phaeothecoidiellaceae fam. nov.
}

\author{
Hongsanan $\mathrm{S}^{1,2,3}$, Zhao RL ${ }^{4}$, Hyde $\mathrm{KD}^{1,2,3}$ \\ ${ }^{1}$ World Agroforestry Centre, East and Central Asia, Kunming 650201, Yunnan, PR China \\ ${ }^{2}$ Key Laboratory of Economic Plants and Biotechnology, Kunming Institute of Botany, Chinese Academy of Sciences, \\ Lanhei Road No 132, Panlong District, Kunming, Yunnan Province, 650201, PR China \\ ${ }^{3}$ Center of Excellence in Fungal Research, Mae Fah Luang University, Chiang Rai, 57100, Thailand \\ ${ }^{4}$ The State Key Laboratory of Mycology, Institute of Microbiology, Chinese Academy of Science No.3 1st Beichen West \\ Rd., Chaoyang District, Beijing 100101, PR China
}

Hongsanan S, Zhao RL, Hyde KD. 2017 - A new species of Chaetothyrina on branches of mango, and introducing Phaeothecoidiellaceae fam. nov. Mycosphere 8 (1), 137-146, Doi 10.5943/mycosphere/8/1/13

\begin{abstract}
The new family Phaeothecoidiellaceae, introduced in this paper, comprises several species which cause sooty blotch and flyspeck diseases of several economic fruits. This results in quality issues with fruits and plants, due to the black thallus and small black dots coating the surface. Most species of Phaeothecoidiellaceae are biotrophs and are unculturable without the host material, and direct-sequencing is difficult because of the very small and flattened thyriothecia. Therefore, this fungal group is relative poorly known due to limited sampling and few in-depth studies. "Microthyriales"-like taxa appearing as small black dots on the surface of mango trees were collected in northern Thailand. Taxa were studied based on morphological characters and molecular analyses. Maximum likelihood and Bayesian analyses of combined ITS, LSU and SSU sequence data, indicated that the collection from branches of mango is a previously undescribed species. The new species, Chaetothyrina guttulata, is introduced in this paper with descriptions and illustrations.
\end{abstract}

Key words - Capnodiales - Dothideomycetes - Flyspeck - Phylogeny - Sooty blotch

\section{Introduction}

Sooty blotch and flyspeck disease does not directly damage fruits, but causes marketability problems in economic plants by blemishing fruits and reduces the photosynthesis ability of plants (Miñarro \& Dapena 2012, Zhang et al. 2015). There are several epiphytic fungi which cause sooty blotch and flyspeck disease on the epicuticular wax layer of fruits, leaves and stems of various plants (Batzer et al. 2005, 2010, Yang et al. 2010, Cooley et al. 2011, Gleason et al. 2011, Miñarro \& Dapena 2012, Hao et al. 2013, Zhang et al. 2015). Sooty blotch and flyspeck disease fungi have a wide distribution, and are common in humid temperate regions (Yang et al. 2010, Singtripop et al. 2016). Both diseases can occur together since they are favoured by similar environmental conditions (Wilcox 1994). Sooty blotch differs from flyspeck in having colonies comprising dark mycelial mats, whereas flyspeck has shiny, black, rounded, sclerotia-like bodies and lacks a mycelial mat (Batzer et al. 2005, Frank et al. 2010, Gleason et al. 2011, Mayfield et al. 2013). More 
than 60 taxa of sooty blotch and flyspeck disease fungi are presently known (Díaz Arias et al. 2010). Sooty blotch and flyspeck disease is generally poorly known due to limited sampling and few in-depth studies. Furthermore, identifying sooty blotch and flyspeck disease fungi in culture is difficult due to the very small and flattened thyriothecia (Hickey 1960).

Many sooty blotch and flyspeck disease species belong in the order Microthyriales which are foliar epiphytes and mainly form small, inconspicuous, black dots on the surface of hosts (Wu et al. 2011, Hongsanan et al. 2014a, 2015a). Microthyriales is placed in the class Dothideomycetes (Hyde et al. 2013), and is characterized by flattened thyriothecia appearing as small black dots, with thyriothecial setae in some species, various ostiolar forms, while the basal wall is poorlydeveloped. Asci are bitunicate, and ascospores are uni- to multi-septate and hyaline or brown (Arnaud 1918, Luttrell 1973, von Arx \& Müller 1975, Barr 1987, Kirk et al. 2008, Hyde et al. 2013, Hongsanan et al. 2014a, Singtripop et al. 2016). There are two families accepted in Microthyriales based on morphology, which are Microthyriaceae and Micropeltidaceae (Hyde et al. 2013, Hongsanan et al. 2014a, Wijayawardene et al. 2014, Ariyawansa et al. 2015). The family Microthyriaceae includes foliar biotrophs and saprotrophs, with easily removed thyriothecia, cell walls arranged in parallel rows from a prominent central ostiole to the margin and poorlydeveloped bases, fusiform to cylindrical or elongate asci, and hyaline 2-celled ascospores )Doidge 1942, Müller \& von Arx 1962, Hofmann 2010, Wu et al. 2011, Hyde et al. 2013, Ariyawansa et al. 2015(. Micropeltidaceae includes biotrophs and saprotrophs which are usually found on the lower surface of leaves as black-blue or greenish to black thyriothecia, which are poorly-developed at the base, walls comprising interwoven hyphae, with central ostioles, hyaline and mostly multi transseptate ascospores (Clements \& Shear 1931, Lumbsch \& Huhndorf 2010, Wu et al. 2011, Hyde et al. 2013, Hongsanan et al. 2015b).

The genus Chaetothyrina causes flyspeck disease on various plants worldwide, such as $C$. musarum (Speg.) Theiss. and C. panamensis (F. Stevens \& Dorman) Arx, which occurs on banana and Oncoba laurina (Müller \& von Arx 1962) respectively. Chaetothyrina was introduced by Theissen (1913), the type species is C. musarum. A reference type specimen and sequence data generated from ITS, LSU and SSU sequence data were provided by Singtripop et al. (2016). The phylogenetic placement of Chaetothyrina is now shown to lie within Capnodiales (Singtripop et al. 2016, and this study). The morphological characters are similar to Micropeltidaceae in Microthyriales; but differs in having inconspicuous superficial hyphae (sometimes this may be absent) and thyriothecia with setae (Reynolds \& Gilbert 2005). Ascospores in Micropeltidaceae mostly have up to two septa, while Chaetothyrina has 1-septate ascospores. However, Chaetothyrina is placed in the new family Phaeothecoidiellaceae (Capnodiales), based on its phylogenetic placement. Chaetothyrina contains 14 records in Index Fungorum (2016), and sequence data for only two species are available in GenBank.

In this study, we introduce a new species, Chaetothyrina guttulata in the new family Phaeothecoidiellaceae (Capnodiales). The new taxon is compared morphologically with other species in the genus Chaetothyrina, in Micropeltidaceae, and in Capnodiales. The introduction of Chaetothyrina is also supported by molecular analysis of the ITS, LSU and SSU sequence data.

\section{Materials \& Methods}

\section{Isolation and morphology study}

"Microthyriales"-like taxa were collected from Chiang Rai Province in northern Thailand and ascomata were studied by free-hand section under a stereomicroscope. A compound microscope was used to observe asci and ascospore characters. Slides were preserved in lactoglycerol after photographing (Nikon 80i). Measurements were determined using Tarosoft (R) Image Frame Work v. 0.9.7. Single spore isolation was carried out using the methods in Chomnunti et al. (2014). The type specimen of the new species is deposited in the Mae Fah Luang University Herbarium (MFLU), Chiang Rai, Thailand, and ex-type cultures in Mae Fah Luang University 
Culture Collection (MFLUCC), and in Kunming Institute of Botany (KIB). Faces of Fungi numbers and Index Fungorum numbers are provided (Jayasiri et al. 2015, Index Fungorum 2016).

DNA isolation, amplification and sequencing

Fungal isolates were grown on potato dextrose agar (PDA) for 15 days at $25-30{ }^{\circ} \mathrm{C}$ with dark/ $12 \mathrm{~h}$ with light. Genomic DNA was extracted from mycelium using a Forensic Genomic DNA Extraction Kit (OMEGA Bio-tek); following the instructions. The conditions for the polymerase chain reaction (PCR) were determined using the primer pairs ITS1/ITS4 to amplify internal transcribed spacer region (ITS), LROR/LR5 to amplify the large subunit region (LSU), and NS1/NS4 to amplify the small subunit region (SSU). The amplification conditions were as described in Hongsanan et al. (2014b). PCR products were visualized on $1 \%$ agarose electrophoresis gels, and sequencing followed Li et al. (2015). Sequences generated for the new species are deposited in GenBank.

\section{Phylogenetic analysis}

Sequences that relate to Chaetothyrina species were obtained from GenBank following previous publications to supplement the dataset (Table 1, Ariyawansa et al. 2015, Hongsanan et al. 2015b, Singtripop et al. 2016). Forty sequences were downloaded and are included with the newly generated sequences from this study, Chaetothyrina guttulata (Fig. 1). Venturia inaequalis (Cooke) G. Winter was selected as outgroup taxon )Table 1(. The phylogenetic tree for ITS sequence data was generated separately from the phylogenic tree of combined LSU and SSU sequence data (Fig. 2). The data set were aligned by using MAFFT (Katoh et al. 2009), checked and aligned manually using Bioedit )Hall 1999(. Maximum likelihood analysis was carried out by raxmlGUIv.0.9b2 (Silvestro \& Michalak 2012). The search strategy was set to bootstrapping with GTRGAMMA model analysis. The number of replicates was inferred using the stopping criterion (Pattengale et al. 2009). Maximum likelihood bootstrap values were produced from 1,000 repetitions by RAxML analysis, and the values which are equal or greater than $50 \%$ are given to the left of each node (Figs.1, 2). The MrModeltest 2.2 was used to perform the model of evolution (Nylander 2008). Posterior probabilities were set by MCMC sampling in MrBayes v3.1.2 (Huelsenbeck \& Ronquist 2001, Zhaxybayeva \& Gogarten 2002), following Cai et al. (2006, 2008). Posterior probabilities values (PP) which are equal or greater than 0.90 are given at the right of each node (Figs 1, 2). Phylogenetic trees were viewed and arranged using MEGA v5.2.1 (Tamura et al. 2011).

\section{Results}

\section{Molecular phylogeny}

The LSU and SSU sequence data from taxa in Capnodiaceae, Dissoconiaceae, Euantennariaceae, Micropeltidaceae, Mycosphaerellaceae, Myriangiaceae Schizothyriaceae and Teratosphaeriaceae were included in the phylogenetic analysis; Venturia inaequalis was used as outgroup taxon (Table 1). The best tree of RAxML maximum likelihood (ML) is provided with Bayesian values at each node (Fig. 1). Phylogenetic analyses indicate that nine stains from Micropeltidaceae cluster within Capnodiales (93\% ML, 1.0 PP support), however, they are morphologically similar to Microthyriales; the result is similar to previous studies (Ismail et al. 2016, Singtripop et al. 2016). Four stains from the genus Chaetothyrina cluster within the clade of Micropeltidaceae in Capnodiales, and are closely related to Stomiopeltis versicolor (Desm.) Arx. In combined LSU and SSU tree, Chaetothyrina guttulata is closely related to C. musarum which is a reference type species of the genus and was found on Musa sp. (97\% ML, 1.0 PP). The phylogenetic tree generated from ITS sequence data also shows that $C$. guttulata is a new species (Fig. 2). In both phylogenetic trees, Chaetothyrina guttulata is a distinct species. Consequently, we introduce $C$. guttulata as a new species of Chaetothyrina. 
Table 1. Taxa used in the phylogenetic analysis with GenBank accession numbers (LSU and SSU) and species voucher/culture numbers.

\begin{tabular}{|c|c|c|c|c|}
\hline \multirow{2}{*}{ Species } & \multirow{2}{*}{$\begin{array}{l}\text { Voucher/culture } \\
\text { numbers }\end{array}$} & \multicolumn{3}{|c|}{ Accession numbers } \\
\hline & & $L S U$ & $S S U$ & ITS \\
\hline Austroafricana associata & CBS 120732 & KF901829 & - & KF901512 \\
\hline Capnobotryella renispora & CBS 215.90 & GU214399 & AY220613 & AY220613 \\
\hline Capnodium coffeae & CBS 147.52 & GU214400 & DQ247808 & AJ244239 \\
\hline Chaetothyrina guttulata & MFLUCC15-1080 & KU358917 & KU358916 & KX372277 \\
\hline Chaetothyrina guttulata & MFLUCC15-1081 & KU358914 & KU358915 & KX372276 \\
\hline Chaetothyrina musarum & MFLUCC15-0383 & KU710171 & KU710174 & KX372275 \\
\hline Devriesia strelitziae & CBS 122379 & GU301810 & GU296146 & EU436763 \\
\hline Dissoconium aciculare & CBS 204.89 & GU214419 & GU214523 & AY725520 \\
\hline Dissoconium dekkeri & CBS 342.86 & JN232431 & - & - \\
\hline Dothistroma septosporum & CBS: 112498 & GQ852597 & JX901744 & JX901744 \\
\hline Hortaea werneckii & 4263 & JX141471 & JX141470 & DQ336709 \\
\hline Houjia yanglingensis & YHLB20 & GQ433630 & - & GQ433629 \\
\hline Houjia yanglingensis & YHJN13 & GQ433631 & - & GQ433628 \\
\hline Leptoxyphium cacuminum & MFLUCC10-0049 & JN832602 & JN832587 & \\
\hline Mycosphaerella ellipsoidea & CBS: 110843 & GQ852602 & AY725545 & AY725545 \\
\hline Mycosphaerella endophytica & CBS:114662 & GQ852603 & DQ302953 & DQ302953 \\
\hline Mycosphaerella irregulariramosa & CBS:111211 & GQ852609 & & KF901706 \\
\hline Mycosphaerella keniensis & CBS:111001 & GQ852610 & - & - \\
\hline Mycosphaerella punctiformis & CBS 113265 & NG027571 & AY490775 & AY490763 \\
\hline Myriangium duriaei & CBS 260.36 & NG027579 & AF242266 & - \\
\hline Myriangium hispanicum & CBS 247.33 & GU301854 & GU296180 & - \\
\hline Phaeothecoidiella illinoisensis & CBS: 125223 & GU117901 & - & GU117897 \\
\hline Phaeothecoidiella missouriensis & CBS:118959 & GU117903 & - & GU117899 \\
\hline Phragmocapnias asiticus & MFLUCC10-0062 & JN832612 & JN832597 & - \\
\hline Phragmocapnias betle & MFLUCC10-0053 & JN832606 & JN832591 & - \\
\hline Phragmocapnias betle & MFLUCC10-0050 & JN832605 & JN832590 & - \\
\hline Pseudoveronaea ellipsoidea & MI3 34F1a & JQ622103 & - & FJ425205 \\
\hline Pseudoveronaea obclavata & UIF3 & AY598916 & - & AY598877 \\
\hline Ramichloridium apiculatum & CBS 400.76 & EU041851 & EU041794 & EU041794 \\
\hline Rasutoria pseudotsugae & rapssd & EF114704 & EF114729 & EF114687 \\
\hline Rasutoria tsugae & ratstk & EF114705 & EF114730 & EF114688 \\
\hline Schizothyrium pomi & CUA1a & AY598895 & - & EF164898 \\
\hline Schizothyrium pomi & Flyspeck1924-Zj001 & AY598894 & - & AY598848 \\
\hline Scorias spongiosa & MFLUCC10-0084 & JN832586 & JN832601 & - \\
\hline Scorias spongiosa & AFTOL-ID 1594 & DQ678075 & DQ678024 & - \\
\hline Stomiopeltis versicolor & GA3 23C2b & FJ147163 & - & FJ438375 \\
\hline Venturia inaequalis & CBS 815.69 & GU301878 & GU296204 & - \\
\hline Zygophiala cryptogama & KY1 1.2A1c & EF164902 & - & EF164900 \\
\hline Zygophiala_tardicrescens & MWA1a & EF164901 & - & AY598856 \\
\hline Zygophiala_wisconsinensis & MSTA8a & AY598897 & - & AY598853 \\
\hline
\end{tabular}

\section{Taxonomy}

Phaeothecoidiellaceae K.D. Hyde \& Hongsanan, fam. nov.

Index Fungorum number: IF552766; Facesoffungi number: FoF02883

Pathogenic on host surface. Sexual morph: Thallus very thin, covering surface of host with dark brown hyphae. Superficial hyphae septate, not constricted at the septum, branched, brown to dark brown. Thyriothecia superficial, circular, flattened, base poorly developed, thin-walled, brown to dark brown, central ostiole present, thyriothecial setae present. Setae arising from the surface of thyriothecia, brown to dark brown, smooth-walled. Upper wall dark brown of cells of textura epidermoidea. Peridium comprising cells of textura angularis or flattened cells, inner layer hyaline, outer layer dark brown or reddish brown. Hamathecium hyaline, pseudoparaphyses. Asci 8-spored, 
bitunicate, subcylindrical to obovoid, pedicellate or apedicellate, ocular chamber. Ascospores ellipsoid, 1-septate, hyaline. Asexual morph: Hyphomycetous. Colonies effuse to punctiform. Mycelium septate, branched, brown to dark brown, warty hyphae, sometimes encased in a mucilaginous sheath. Endoconidia phragmospores inside hyphae, pale brown to brown, aseptate, thin-walled, subcylindrical to broadly ellipsoid, roughened upon release; sometimes with a thin, inconspicuous septum. Conidiophores reduced to conidiogenous cells, intercalary, dark-brown, subcylindrical to cuneiform, with conidiogenesis holoblastic to phialidic. Conidia broadly ellipsoid to subcylindrical or obclavate, truncate at base, rounded at apex, transversely septate, brown, tapering to a cuneiform with a truncate hilum at base.

Type: Phaeothecoidiella Batzer \& Crous, in Yang et al., Persoonia 24: 30 (2010)
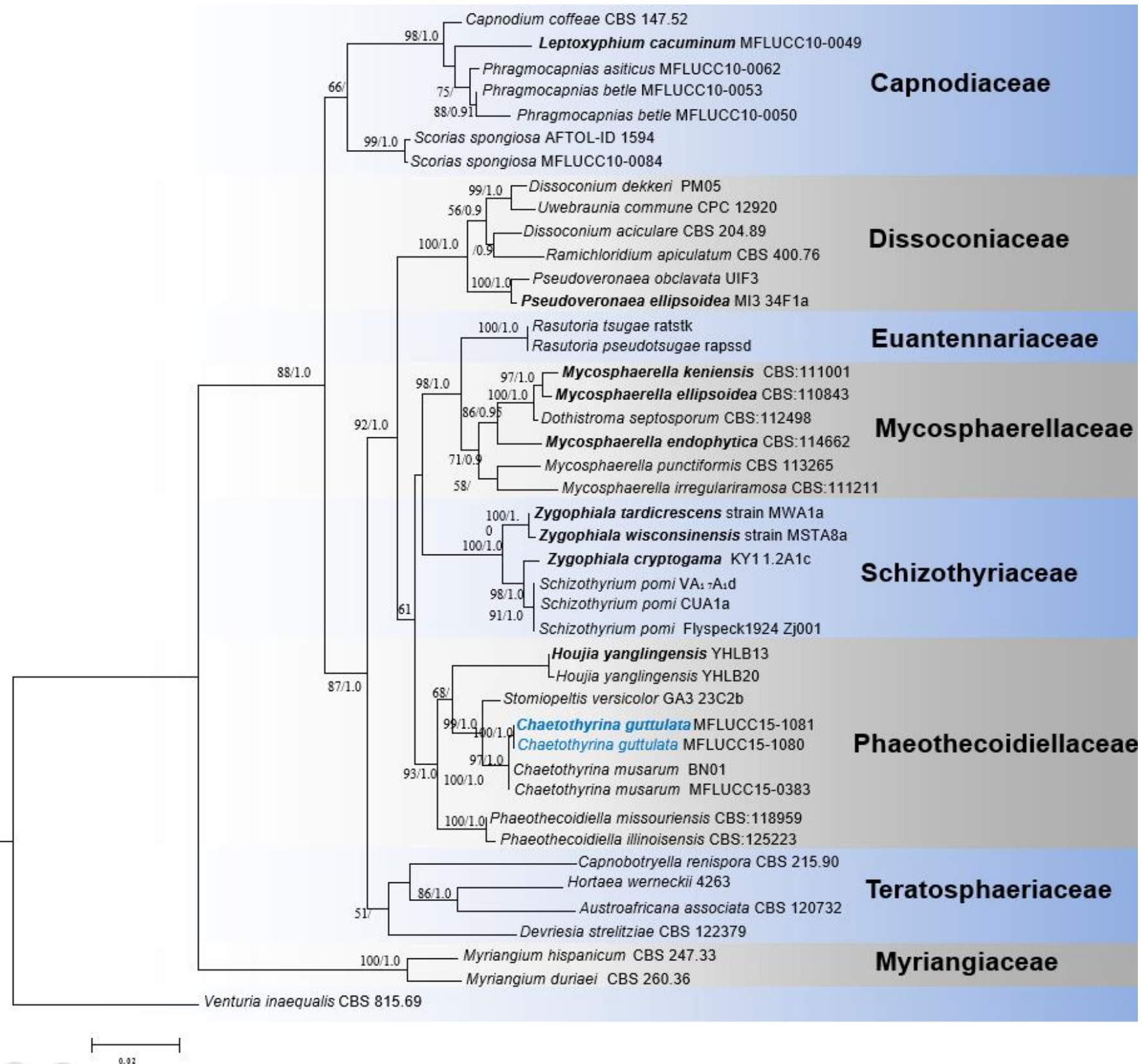

Figure 1 Maximum likelihood phylogenetic tree generated from RAxML analysis of combined LSU and SSU sequence data. The first set of numbers above the nodes are RAxML bootstrap values. The second set of numbers above the nodes are Bayesian posterior probabilities. Strain numbers are indicated after species names. Types strains are in black bold, sequence data of new species are in blue. 


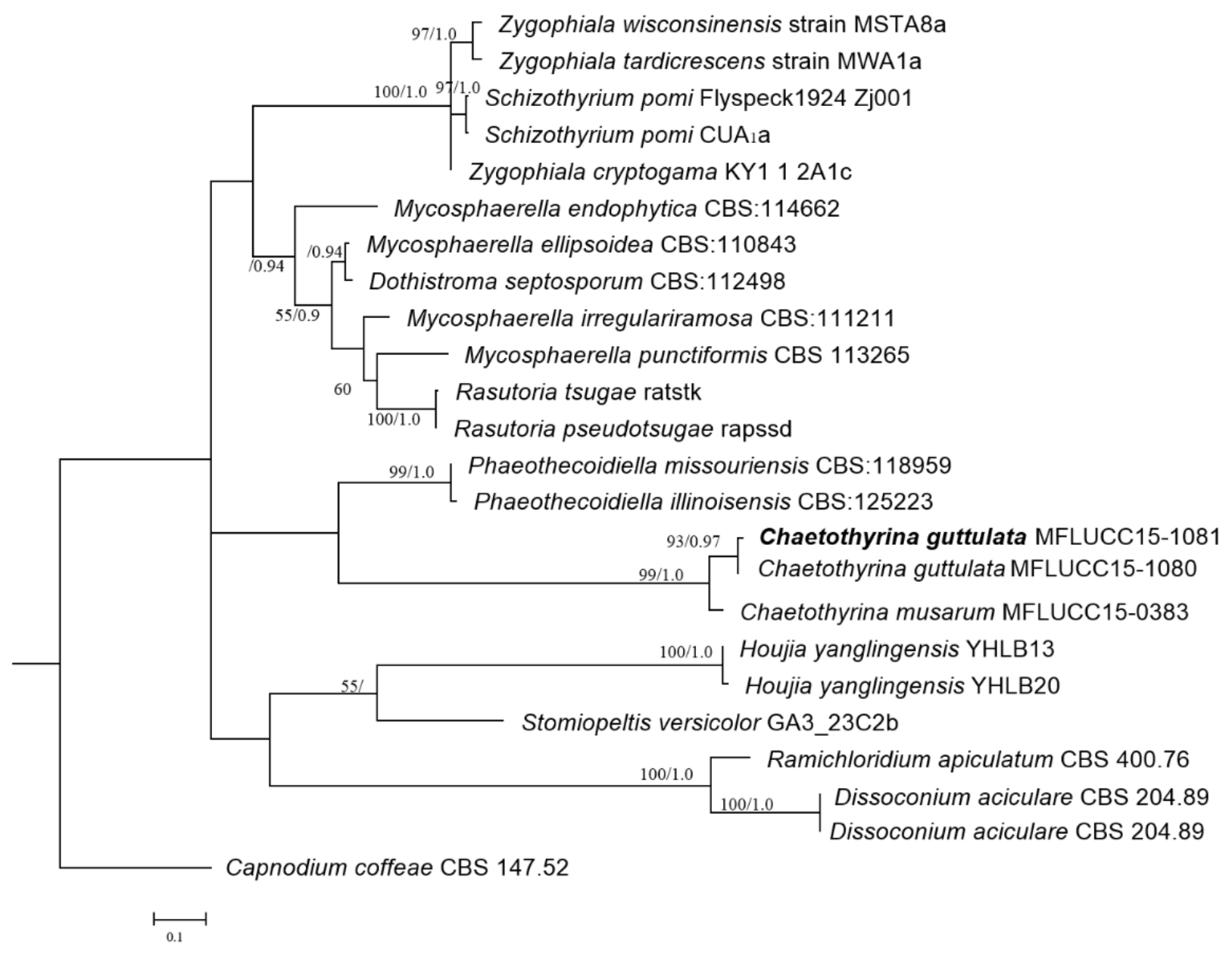

Figure 2 - Maximum likelihood phylogenetic tree generated from RAxML analysis of ITS sequence data. The first set of numbers above the nodes are RAxML bootstrap values. The second set of numbers above the nodes are Bayesian posterior probabilities. Strain numbers are indicated after species names. The type sequence data of new species is in bold.

Notes: Houjia and Phaeothecoidiella were introduced and placed in Micropeltidaceae, Microthyriales based on their morphology by Yang et al. (2010). However, phylogenetic analysis showed that these taxa formed a distinct lineage sister to the familial clades of Dissoconiaceae, Mycosphaerellaceae and Schizothyriaceae in Capnodiales (Yang et al. 2010). In our analysis, we confirmed the placement of Chaetothyrina, Houjia and Phaeothecoidiella and introduce the new family Phaeothecoidiellaceae to accommodate these taxa.

Chaetothyrina guttulata Hongsanan \& K.D. Hyde, sp. nov.

Index Fungorum number: IF551933, Facesoffungi number: FoF01884, Fig. 3

Etymology: guttulata referring to the ascospores which have 2-guttules in each cell.

Type: MFLU16-0299.

Epiphytes appearing as small black dots on the surface of branches of Mangifera indica. Thallus very thin, especially around the thyriothecia, covering surface of host with dark brown hyphae. Superficial hyphae $3 \mu \mathrm{m}$ wide, septate, not constricted at the septum, branched, brown to dark brown, not dense. Sexual morph: Thyriothecia 175-185 × 47-56 $\mu \mathrm{m}(\bar{x}=180 \times 52 \mu \mathrm{m}, \mathrm{n}=5$, superficial, solitary, circular, flattened, base poorly developed, thin-walled, brown to dark brown, rounded, easily removed from host surface, central ostiole present at maturity, thyriothecial setae present, but poorly developed. Setae $60-85 \mu \mathrm{m}$ long $(\bar{x}=76 \mu \mathrm{m}, \mathrm{n}=10)$, arising from the surface of thyriothecia, straight, unbranched, septate, brown to dark brown, darkened at the septa, hyaline at the apex, smooth-walled. Ostiole 28-31 $\mu \mathrm{m}$ diam. $(\bar{x}=30 \mu \mathrm{m}, \mathrm{n}=5$ (, comprising subcylindrical cells, light brown. Upper wall comprising 2-3 layers, inner layer hyaline, outer layer dark brown of 
cells of textura epidermoidea. Peridium $10-14 \mu \mathrm{m}(\bar{x}=11 \mu \mathrm{m}, \mathrm{n}=10)$, comprising cells of textura angularis or flattened cells, inner layer hyaline, outer layer dark brown or reddish brown. Hamathecium of $2 \mu \mathrm{m}$ wide, septate, hyaline, pseudoparaphyses. Asci $32-37 \times 12-14 \mu \mathrm{m}(\bar{x}=35 \times$ $13 \mu \mathrm{m}, \mathrm{n}=10$ (, 8-spored, bitunicate, subcylindrical to obovoid, short pedicellate or sometimes apedicellate, ocular chamber long when immature. Ascospores 14-16 $\times 4-5 \mu \mathrm{m}(\bar{x}=15 \times 4.5 \mu \mathrm{m}$, $\mathrm{n}=10$ (, bi to tri-seriate, ellipsoid, 1-septate, constricted at the septum, upper cell wider than lower cell, tapering towards the base, hyaline, with 2 guttules in each cell. Asexual morph: Undetermined.
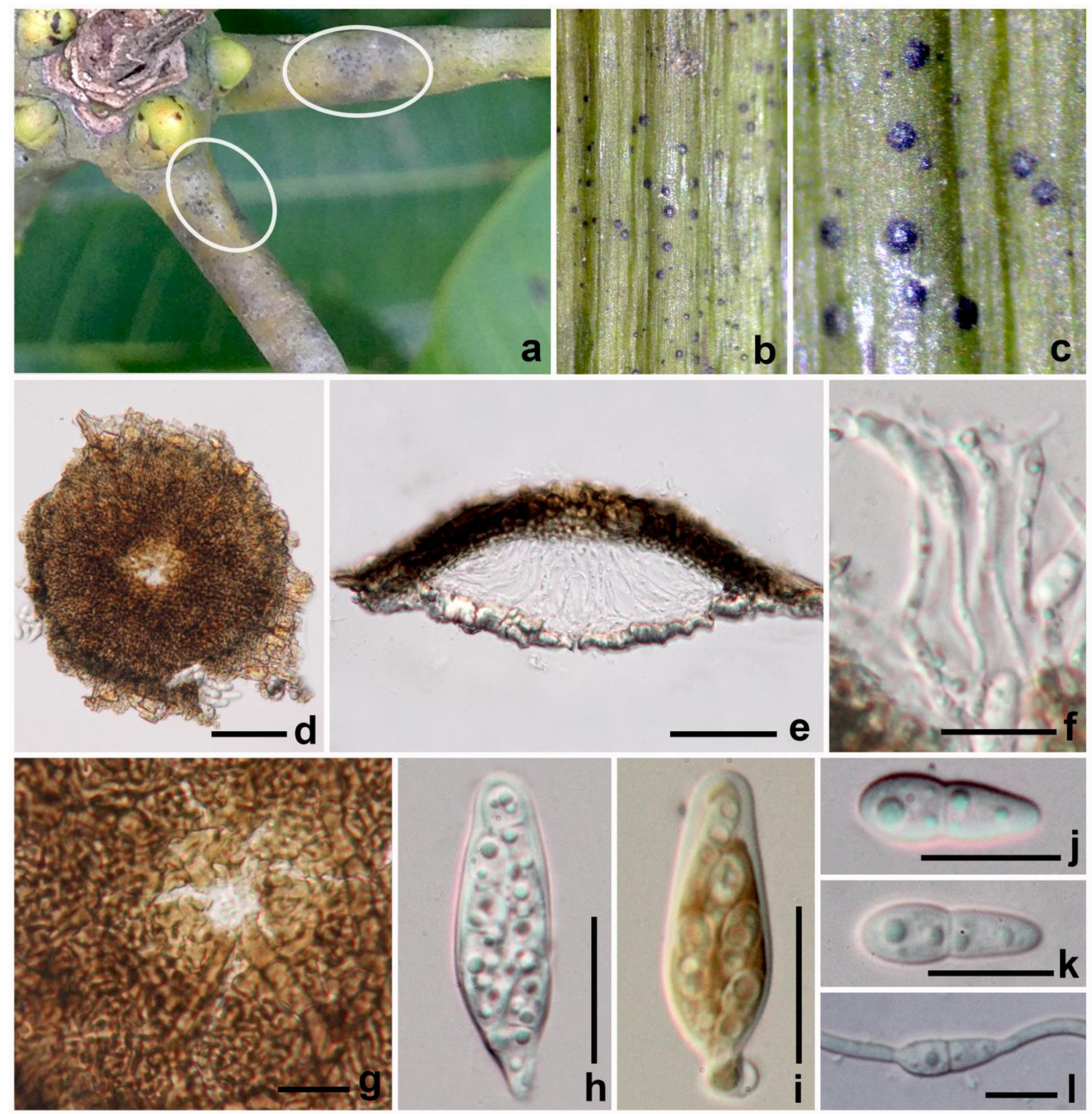

Figure 3 - Chaetothyrina guttulata. )holotype(. a. Young budding shoot of mango with small black dots of thyriothecia. b, c. Thyriothecia on the surface of young budding shoot of mango. d. Thyriothecium when viewed in squash mount. e. Section through thyriothecium. f. Thyriothecial setae. g. Hamathecium. h. Ostiole. i. Ascus. j. Ascus in Melzer's reagent. k, 1. Ascospores with 2guttules. $\mathrm{m}$. Germinated ascospore. Scale bars: $d, e=50 \mu \mathrm{m}, \mathrm{f}-\mathrm{h}, \mathrm{k}-\mathrm{m}=10 \mu \mathrm{m}, \mathrm{i}, \mathrm{j}=20 \mu \mathrm{m}$. 
Culture characteristics: Ascospore germinating on PDA at $25-28{ }^{\circ} \mathrm{C}$ for $12 \mathrm{~h}$ of light $/ 12 \mathrm{~h}$ of dark, hyphae germinating from both cells of the ascospore, septate, not constricted and slightly darkened at the septum, hyaline to grayish initially, and become dark grey to black later, darker at the center. Colonies slow growing, reaching $2 \mathrm{~cm}$ diam. after 5 days on PDA, colony superficial to erumpent, surface smooth, velvety.

Material examined: THAILAND. Chiang Rai Province: Tasud, Ban Doo, Pong Phra Bat, on branches of Mangifera indica, 13 September 2015, S. Hongsanan, MM03 (MFLU16-0299, holotype); ibid. (isotype in KUN), ex-type living culture, MFLUCC15-1081; THAILAND. Chiang Rai Province: Tasud, Ban Doo, CRU, on branches of Mangifera indica, 13 September 2015, S. Hongsanan, MM02 (MFLU16-0256), living culture, MFLUCC 15-1080.

\section{Discussion}

Chaetothyrina guttulata is most typical of C. applanata (Ellis \& G. Martin) M.E. Barr in having two guttules in each cell of the ascospores. However, C. guttulata has dark brown thyriothecia, which are slightly darker at the margin and 1-septate ascospores which are narrow at the base and are constricted at the septum, while $C$. applanata has thyriothecia that are blackish brown above and hyaline at the base, 1-septate ascospores with obtuse ends, and lack constrictions at the septum. Chaetothyrina guttulata is also similar to C. musarum, based on its thyriothecia with setae and 1-septate ascospores, although the thyriothecial setae in $C$. guttulata are poorly developed. Chaetothyrina guttulata has more flattened thyriothecia than $C$. musarum, and has 2 guttules in each cell of the ascospores, with constrictions at the septum, tapering towards the base, while $C$. musarum has aguttulate ascospores, with slight constrictions at the septum, and a basal cell with rounded ends. We also considered the size of both $C$. guttulata and C. musarum and found that the ascospores of $C$. guttulata are longer than in $C$. musarum. Phylogenetic analyses of combined LSU and SSU sequence data and the analyses for ITS sequence data demonstrate that $C$. guttulata belongs in Chaetothyrina and is closely related to C. musarum (Figs 1, 2). Chaetothyrina species clustered with species of Phaeothecoidiella and Houjia as a distinct clade in Capnodiales although the morphology of Chaetothyrina is similar to Micropeltidaceae in Microthyriales. Sequence data of Micropeltis which is the generic type of Micropeltidaceae shown the phylogenetic placement of this family outside Capnodiales (Wu et al. 2011, Hongsanan et al. 2015a, Singtripop et al. 2016). Thus, we introduce the new family Phaeothecoidiellaceae in this paper to accommodate Chaetothyrina, Houjia and Phaeothecoidiella in Capnodiales.

\section{Acknowledgements}

Kevin D. Hyde thanks the Chinese Academy of Sciences, project number 2013T2S0030, for the award of Visiting Professorship for Senior International Scientists at Kunming Institute of Botany.

\section{References}

Ariyawansa HA, Hyde KD, Jayasiri SC, Buyck B et al. 2015 - Fungal Diversity Notes 111-246 Taxonomic and phylogenetic contributions to fungal taxa. Fungal Diversity 75, 27-274.

Arnaud G. 1918 - Lés Asterinées. Annals d'École National d'Agriculture de Montpellier Série 2 $16,1-288$.

Barr ME 1987 - New taxa and combinations in the Louculoascomycetes. Mycotaxon 29, 501-505. Batzer JC, Gleason ML, Harrington TC, Tiffany LH. 2005 - Expansion of the sooty blotch and flyspeck complex on apples based on analysis of ribosomal DNA gene sequences and morphology. Mycologia 97, 1268-1286.

Batzer JC, Hernandez Rincon S, Mueller DS, Petersen BJ et al. 2010 - Effect of temperature and nutrient concentration on the growth of six species of sooty blotch and flyspeck fungi. Phytopathologia Mediterranea 49, 3-10. 
Cai L, Guo XY, Hyde KD 2008 - Morphological and molecular characterization of a new anamorphic genus Cheirosporium, from freshwater in China. Persoonia 20, 53-58.

Cai L, Jeewon R, Hyde KD. 2006 - Phylogenetic investigations of Sordariaceae based on multiple gene sequences and morphology. Mycological Research 110, 137-150.

Chomnunti P, Hongsanan S, Hudson BA, Tian Q et al. 2014 - The sooty moulds. Fungal Diversity $66,1-36$.

Clements FE, Shear CL. 1931 - Genera of fungi 2 Vol. i-vii. H.W. Wilson, USA, New York, 496 p.

Cooley DR, Rosenberger DA, Gleason ML, Koehler G et al. 2011 - Variability Among Forecast Models for the Apple Sooty Blotch/Flyspeck Disease Complex. Plant Disease 95, 1179-1186.

Díaz Arias MM, Batzer JC, Wang Wong A, Bost SC et al. 2010 - Diversity and biogeography of sooty blotch and flyspeck fungi on apple in the eastern and midwestern United States. Phytopathology 100, 345-355.

Doidge EM. 1942 - South African Microthyriaceae. Bothalia 4, 273-344.

Frank J, Crous PW, Groenewald JZ, Oertel B et al. 2010 - Microcyclospora and Microcyclosporella: novel genera accommodating epiphytic fungi causing sooty blotch on apple. Persoonia 24, 93-105.

Gleason ML, Batzer JC, Guangyu S, Zhang R et al. 2011 - A new view of sooty blotch and flyspeck. Plant Disease 95: 368-383.

Hall TA. 1999 - BioEdit: a user-friendly biological sequence alignment editor and analysis program for Windows 95/98/NT. Nucleic Acids Symposium Series 41, 95-98.

Hao L, Chen C, Zhang R, Zhu M et al. 2013 - A new species of Scolecobasidium associated with the sooty blotch and flyspeck complex on banana from China. Mycological Progress 12, 489-495.

Hickey KD. 1960 - The sooty blotch and flyspeck diseases of apple with emphasis on variation within Gloeodes pomigena (SCW.) Colby. PhD thesis. Department of Plant Pathology, The Pennsylvania State University, USA.

Hofmann TA. 2010 - Plant parasitic Asterinaceae and Microthyriaceae from the Neotropics (Panama). PhD thesis, The Faculty of Biological Sciences at the J.W. Goethe-University Frankfurt am in, Germany, 408 p.

Hongsanan S, Chomnunti P, Crous PW, Chukeatirote E, Hyde KD. 2014a - Introducing Chaetothyriothecium, a new genus of Microthyriales. Phytotaxa 161, 157-164.

Hongsanan S, Hyde KD, Bahkali AH, Camporesi E et al. 2015b - Fungal Biodiversity Profiles 1120. Cryptogamie Mycologie 36, 355-380.

Hongsanan S, Li YM, Liu JK, Hofmann T et al. 2014b - Revision of genera in Asterinales. Fungal Diversity 68, 1-68.

Hongsanan S, Tian Q, Bahkali AH, Yang JB et al. 2015a - Zeloasperisporiales ord. nov., and two new species of Zeloasperisporium. Cryptogamie Mycologie 36, 301-317.

Huelsenbeck JP, Ronquist F. 2001 - MRBAYES: Bayesian inference of phylogenetic trees. Bioinformatics 17, 754-755.

Hyde KD, Jones EBG, Liu JK, Ariyawansha H et al. 2013 - Families of Dothideomycetes. Fungal Diversity 63, 1-313.

Index Fungorum 2016 - http://www.indexfungorum.org/Names/Names.asp.

Ismail SI, Batzer JC, Harrington TC, Crous PW et al. 2016 - Ancestral state reconstruction infers phytopathogenic origins of sooty blotch and flyspeck fungi on apple. Mycologia 108, 292302.

Jayasiri SC, Hyde KD, Ariyawansa HA, Bhat JD et al. 2015-The Faces of Fungi database: fungal names linked with morphology, phylogeny and human impacts. Fungal Diversity 74, 3-18.

Katoh K, Asimenos G, Toh H. 2009 - Multiple alignment of DNA sequences with MAFFT. Methods in Molecular Biology 537, 39-64.

Kirk PM, Cannon PF, Minter DW, Stalpers JA. 2008 - Ainsworth \& Bisby's dictionary of the fungi, $10^{\text {th }}$ edition. CAB International, Wallingford, UK, $428 \mathrm{p}$. 
Li GJ, Zhao D, Li SF, Wen HA. 2015 - Russula chiui and R. pseudopectinatoides, two new species from southwestern China supported by morphological and molecular evidence. Mycological Progress 14, 33.

Lumbsch HT, Huhndorf SM. 2010 - Outline of Ascomycota-2009. Fieldiana Life Earth Science $1,1-60$.

Luttrell ES. 1973 - Loculoascomycetes. In: Ainsworth GC, Sparrow FK, Sussman AS. (eds) The fungi. An advanced treatise. Academic Press, New York and London, 135-219 pp.

Mayfield DA, Karakaya A, Batzer JC, Blasé JM, Gleason ML. 2013 - Diversity of sooty blotch and flyspeck fungi from apples in northeastern Turkey. European Journal of Plant Pathology $135,805-815$.

Miñarro M, Dapena E. 2012 - Proceedings of the 15th International Conference on Organic Fruit Growing. February 20th-22th, Hohenheim, Germany 47-53.

Müller E, Arx JA von. 1962 - Die Gattungen der didymosporen Pyrenomyceten. Beiträge zur Kryptogamenflora der Schweiz 11, 1-922.

Nylander JAA, Wilgenbusch JC, Warren DL, Swofford DL. 2008 - AWTY (are we there yet?): a system for graphical exploration of MCMC convergence in Bayesian phylogenetics. Bioinformatics 24: 581-583.

Pattengale ND, Alipour M, Bininda-Emonds ORP, Moret BME, Stamatakis A. 2009 - How many bootstrap replicates are necessary? Lecture Notes in Computer Science 5541, 184-200.

Reynolds DR, Gilbert GS. 2005 - Epifoliar fungi from Queensland, Australia. Australian Systematic Botany 18, 265-289.

Silvestro D, Michalak I. 2012 - RaxmlGUI: a graphical front-end for RAxML. Organisms Diversity and Evolution 12, 335-337.

Singtripop C, Hongsanan S, Li J, Silva NID et al. 2016 - Chaetothyrina mangiferae sp. nov., a new species of Chaetothyrina. Phytotaxa 255, 21-33.

Tamura K, Peterson D, Peterson N, Stecher G, Nei M, Kumar S. 2011 - MEGA5: Molecular Evolutionary Genetics Analysis Using Maximum Likelihood, Evolutionary Distance, and Maximum Parsimony Methods. Molecular Biology and Evolution 28, 2731-2739.

Theissen F. 1913 - Über einige Mikrothyriaceen. Annales Mycologici 11, 493-511.

von Arx JA, Müller E. 1975 - A re-evaluation of the bitunicate ascomycetes with key to families and genera. Studies in Mycology 9, 1-159.

Wijayawardene NN, Crous PW, Kirk PM, Hawksworth DL et al. 2014 - Naming and outline of Dothideomycetes-2014. Fungal Diversity 69, 1-55.

Wilcox WF. 1994 - Sooty blotch Gloeodes pomigena (Schwein.) Colby and flyspeck Shizothyrium pomi (Mont. and Fr.) Arx. Tree Fruit Crops, Disease Identification Sheet D 11, 4.

Wu X, Schoch CL, Boonmee S, Bahkali AH, Chomnunti P, Hyde KD. 2011 - A reappraisal of Microthyriaceae. Fungal Diversity 51, 189-248.

Yang HL, Sun GY, Batzer JC, Crous PW, Groenewald JZ, Gleason ML. 2010 - Novel fungal genera and species associated with the sooty blotch and flyspeck complex on apple in China and the United States. Persoonia 24, 29-37.

Zhang M, Gao-Shang S, Han X, Zhang R et al. 2015 - New species and record of Zygophiala (Capnodiales, Mycosphaerellaceae) on apple from Montenegro. Phytotaxa 195, 227-235.

Zhaxybayeva O, Gogarten JP. 2002 - Bootstrap, Bayesian probability and maximum likelihood mapping: exploring new tools for comparative genome analyses. BMC Genomics 3, 4. 